Saudi Journal of Humanities and Social Sciences

Abbreviated Key Title: Saudi J Humanities Soc Sci

ISSN 2415-6256 (Print) | ISSN 2415-6248 (Online)

Scholars Middle East Publishers, Dubai, United Arab Emirates

Journal homepage: https://saudijournals.com/sjhss

Original Research Article

\title{
The Political Participation of Women in Mexico
}

\author{
Lizbeth Gabriela Corral Limas $^{1 *}$, Alma Yolanda Morales Corral ${ }^{2}$, Verónica Ofelia Lozano Sandoval ${ }^{3}$ \\ ${ }^{1}$ Doctor in Administration, Master in Administration, and Bachelor of Public Administration and Political Science. Professor of Autonomous University \\ of Chihuahua, Faculty of Political and Social Sciences, Campus Juarez (Chihuahua, México) \\ ${ }^{2}$ Master in Administration and Bachelor of Law. Professor of Autonomous University of Chihuahua, Faculty of Political and Social Sciences, Campus \\ Juarez(Chihuahua, México) \\ ${ }^{3}$ Master in Administration, Master in Journalist and Bachelor of Communication. Professor of Autonomous University of Chihuahua, Faculty of \\ Political and Social Sciences, Campus Juarez (Chihuahua, México)
}

DOI: $10.36348 /$ sjhss.2020.v05i06.010 $\quad$ | Received: 19.06 .2020 | Accepted: 26.06.2020 | Published: 30.06 .2020

*Corresponding author: Dra. Lizbeth Gabriela Corral Limas

Abstract

This article analyzes the progress made on the political participation of women in Mexico, which, under equal conditions to that of men, is a fundamental aspect for living in a real democracy, understanding it as a system that guarantees human rights and as a method through which positions of power are covered, recognizing, as an essential principle, equality between men and women. The political participation of women opens the scene for social problems to be approached from a different perspective and thus find solutions. From gender quotas in the Mexican electoral system, raised since the 1990 s, to the reform of the Constitution where gender parity is guaranteed in 2014, coupled with the struggle of organizations and the commitment of institutions, served as basis for, in 2018, as a result of the elections, Mexico occupies the fourth position worldwide in terms of the number of women in the Chamber of Deputies, and third position with respect to the Senate. A cross-sectional documentary investigation was carried out to find out the historical development from the first efforts to the current situation.

Keywords: Political participation, women, political discrimination, gender democracy, gender equality, Mexico.

Copyright @ 2020: This is an open-access article distributed under the terms of the Creative Commons Attribution license which permits unrestricted use, distribution, and reproduction in any medium for non-commercial use (NonCommercial, or CC-BY-NC) provided the original author and source are credited.

\section{INTRODUCTION}

Political participation is a term that is linked to the concept and exercise of democracy. For democracy to be legitimate, it necessarily requires political participation, which is the possibility that citizens have to influence the course of political events; that is to say, they are actions carried out by citizens to influence a low or high degree in the affairs of a State. It is, above all, the sum of all those voluntary activities through which the members of a society intervene in the selection of rulers and, directly or indirectly, in the formation or construction of government policies [1].

The classification of political participation: 1) Conventional political participation: It is related to the actions carried out during an electoral process; This participation is promoted from the power of the State and the Constitution. Conventional political participation indicates the right of citizenship; that is, a right to vote that is not measured by social class, party, sex or education. It occurs in all democracy and is a right enshrined in law, so it can be easily controlled and verified, and 2) Unconventional political participation:
Refers to actions such as petitions, legal protests, boycotts, strikes legal and illegal, damage to property, sabotage, personal violence, etc. This participation goes beyond the institutional mechanisms of participation and, on some occasions, makes opposition to the established constitutional legality [1].

Throughout history, women have been excluded from political participation as an independent and autonomous subject, and have had to overcome numerous, and too deep-rooted, barriers of all kinds, political, cultural, social, economic, legal, among others, and face terms such as discrimination, inequality, exclusion, simulation and misogyny, among others, which have been recurrent in the practice of politics in Mexico.

Although the political participation of women has been increasing supported by relevant changes, both in Mexico and in Latin America, there is still a belief in certain sectors that there are "designated" spaces for women, such as meeting the needs of women. The family, raising children, looking after the elderly and in 
general, everything related only to managing the home and as a "complement" to men.

The until very recently limited inclusion of women in politics was a consequence, among other things, of the lack of laws that laid the foundations for equal participation with respect to men, of the lack of support from political parties, to the simulation that was given for the designation of the candidacies, to the scarce incorporation of women in the power structures, to an indifferent society on the subject, etc.

The tendency to ponder democracy has allowed that, on this subject, each day more recognition and value of the role that women have played in the historical evolution, and based, for example, on the adoption of gender quotas and in the gender parity for the integration of the candidates, they have been appreciated as subjects capable of coping beyond the four walls of their home and allowing them to go out into the world, with all its qualities, capacities and preparation, to join, both in public authorities, and to govern alongside men, thereby changing the way of doing politics.

Women find it difficult to exercise freedom in a world that was made so that men, only they, were really free. Now, since fundamental rights are legally recognized, through the procedure of even proposing positive actions that help women come out of their ancestral marginalization, since women in the rule of law, have access to education and to the world of work formally on equal terms with men, it has to be subtler, we must begin by naming all those obstacles that do not allow women to exercise the freedom that they theoretically have [2].

The questions must be asked. Is the woman in a position to create her own identity, that strong self? Are you in a position to live in coherence with yourself and, consequently, to be an active, dissident if necessary part of collective rationality?. It is enough to look at the headlines and images of the newspapers and television news programs day after day to realize that women are not yet a notable part and protagonist of collective rationality. Only the tragedies, which unfortunately are a constant element of the newsworthy, are distributed equally between men and women, however, almost exclusively punishing the female gender when it comes to these types of tragedies that have had to be called, for their special character, gender-. The same does not happen with responsibility positions, whether private or public. The woman in them is almost invisible. Reason from which it is easy to deduce that perhaps her identity is not very satisfactory for herself. If women appear little in the news - identifiable - that is, notorious, it seems inevitable to deduce that women are poorly referenced in this world that systematically does not see them. For whatever reason, that 50 percent of women living in today's societies are in hiding. Either nobody is interested in what they do or what they do is of no interest. Isn't that tangible proof that they are not part of public discourse? [2].

\section{METHOD}

The type of the research was a cross-sectional documentary investigation, that was carried out to find out the historical development from the first efforts to the current situation of the political participation of women in Mexico.

\section{RESULTS \\ Political Discrimination against Women}

Gender democracy is complete democracy, as long as women and men continue to exist such an unequal distribution of positions of power and decision, as well as work, income and time, in the State and society there will be a deficit democratic. It is revealed that our democracy is still incomplete. The problem of how social and economic structures should be shaped has not yet been resolved, but also the private forms of coexistence of women, men and children, to guarantee a political space for democracy, that is, for it to finally come true [3].

Awareness of discrimination suffered by women is not easy in a society where they are apparently free and a great capacity is required to recognize that equality between the sexes is an illusion. For this reason, despite establishing the principle of gender equality as a cultural value, the evident feminine subordination became what has been called "nameless oppression" [4].

The right to political participation encompasses a larger context that contains: 1 . The right to freely choose popular representatives. 2 . The right to freely belong to a political party or any other type of institution set forth by electoral laws. 3 . The right to be able to function as a candidate for popularly elected positions. 4. The right to promote and participate in public policies that reflect the fundamental needs of the community [4].

The exercise of women's vote and their participation in positions of popular election are of equal relevance and that is why it has been determined that parties must register a mínimum of $50 \%$ of women on their list [4].

Regarding gender equality in political participation, the country signed the Convention on the Political Rights of Women (1953): "wishing to equalize the condition of men and women in the enjoyment and excersice of political rights", With three main commitments that today are part of the discourse of women's equality: exercising the right to vote, being elegible and holding public office. This commitment was reaffirmed in Article 7 of the Convention on the 
Elimination of All Forms of Discrimination against Women (1979) [4].

Indeed, we easily find that one woman is different from another, but this singularity results from a lesser relevance in terms of the structural inequality that women present with respect to men. The malefemale relationship in modern societies has inequality as a norm [5].

The most widely recognized model in the discussion about the woman-man-society relationship explains how, from the most contemporary to the most archaic societies, they are structured under basic principles that penetrate the entire social organization and take root in the family. It is the patriarchal order, which is characterized by the institutionalized authority and domination of men over women and their children in the family unit, as part of a sexual policy in the terms defined by Kate Millet. "The assignment of the private sphere to women and the public sphere to men appears, then, as part of a policy in the Weberian sense of Herrschaft (domination and subordination)". Separation and hierarchization that put the adult male above, and with authority over, the female and the young male. For this authority to be exercised, patriarchy must dominate the entire organization of society, of production and consumption, politics, law and culture. Interpersonal relationships are also marked by domination and violence that originate in the culture and institutions of patriarchy. Without the patriarchal family, patriarchy would be unmasked as an arbitrary domination and would end up being overthrown by the rebellion of "half of heaven" kept under submission throughout history [5].

As an example of progress on the subject, the reforms to Article 5 can be observed. of the General Law for Equality between Women and Men, which was published in the Official Gazette of the Federation on August 2, 2006, whose last reform dates from June 14, 2018 and which establishes a series of concepts in favor of the political participation of women, published in the Official Gazette of the Federation on November 14, 2011, which spelled out: I. Affirmative Actions. It is the set of measures of a temporary corrective, compensatory and / or promotional nature, aimed at accelerating substantive equality between women and men; II. Discrimination. Any distinction, exclusion or restriction that, based on ethnic or national origin, sex, age, disability, social or economic condition, health conditions, pregnancy, language, religion, opinions, sexual preferences, marital status or any other, has for effect to impede or annul the recognition or exercise of the rights and real equality of opportunities of people; III. Discrimination against Women. Any distinction, exclusion or restriction based on sex that has the object or result of impairing or nullifying the recognition, enjoyment or exercise by women, regardless of their marital status, based on the equality of men and women, of the human rights and fundamental freedoms in the political, economic, social, cultural and civil spheres or in any other sphere; IV. Gender equality. Situation in which women and men have the same possibilities and opportunities to access, control and benefit the goods, services and resources of society, as well as decisionmaking in all areas of social, economic and political life, cultural and family; V. Substantive Equality. It is access to the same treatment and opportunities for the recognition, enjoyment or exercise of human rights and fundamental freedoms; SAW. Gender Perspective. Concept that refers to the methodology and mechanisms that allow identifying, questioning and evaluating discrimination, inequality and exclusion of women, which is intended to be justified based on the biological differences between women and men, as well as the actions that must be taken to act on gender factors and create the conditions for change that allow progress in the construction of gender equality; VII. Transversality. It is the process that guarantees the incorporation of the gender perspective in order to assess the implications for women and men of any action that is scheduled, dealing with legislation, public policies, administrative, economic and cultural activities in institutions public and private [6].

In other words, ad hoc concepts were incorporated into the reality of our country to strengthen the fact that women can participate in politics in a favorable setting. And, although the mere presence of women in decisión-making positions, the sp-called "descriptive representation", does not generaye substantive equality per se, it is a first step to make women visible in decisión-making spaces and to eventually, advance in promoting an agenda of substantive gender equality and non-discrimination towards structurlly disadvantaged populations, wich is called "substantive representation" [7].

\section{Historical overview of the political participation of women in Mexico}

It is undeniable that the scope of women's political participation in Mexico today is the result of more than a century of events, and among the most notable years and events are the following:

In 1916, in the states of Chiapas, Yucatan and Tabasco, women were granted legal equality to vote and be eligible for public office of popular election. In 1922, in Yucatan, the right of women to participate in municipal and state elections was recognized.

In 1923, the first Mexican elected to the local Congress for the Fifth District in Yucatan, Elvira Carrillo Puerto, and the first female governor in Mérida, Yucatán, Rosa Torres, had. In addition, San Luis Potosí approves the law that allows literate women to participate in electoral processes. 
Later, in 1925, the state of Chiapas granted the vote to women in the municipal elections. For 1936, a decree is issued in the Puebla state electoral law, where the vote is granted to Puebla women.

Then, in 1938, the first woman Municipal President was held in Chilpancingo, Guerrero, Aurora Meza Andraca. In 1947, the right of women to vote and to be voted in municipal electoral processes was granted at the national level.

For 1952, the first Federal Deputy for Baja California was held, which was Aurora Jiménez de Palacios.

Then, in 1953, President Adolfo Ruiz Cortines issued the reform to articles 34 and 115, section I, Constitutional. Article 34 is published in the DOF "Men and women who, having the quality of Mexicans, also meet the following requirements: have reached the age of 18 , being married, or 21 if they are not, and have an honest way of living.

In 1964, there were the first Senators in Mexico, María Lavalle Urbina and Alicia Arellano Tapia.

Later, in 1965, the first female president of the Senate was María Lavalle Urbina. In 1979, the first woman elected to a governorship was Griselda Álvarez, in Colima.

Then, in 1988, the first woman nominated as a candidate for President of the Republic, was Rosario Ibarra.

In 1993 the proposal to COFIPE was approved: "The political parties will promote, in the terms determined by their internal documents, a greater participation of women in the political life of the country, through their nomination for positions of popular election".

Then, in 1996, the reform in COFIPE was approved, which states: "The political parties will consider in their statutes that the candidacies for deputies and senators do not exceed $70 \%$ for the same gender. They will also promote the political participation of women.

In 2002 it is established that, if a political party or coalition does not comply with the provisions of gender quotas, it will be required to rectify the application for registration of candidacies. In case of not doing so, it will issue a public warning and in the event of recidivism, it will be sanctioned with the refusal of the registration of corresponding applications.
For 2008, the COFIPE reform was established, which establishes the gender quota in a proportion of $60 \%-40 \%$.

In 2012, the COFIPE was reformed, which indicates the gender quota at $50 \%$ for both owners and substitutes. This will end the practice of registering women as owners and men as substitutes, the reform will take effect for the 2015 elections [8].

\section{The right to vote for women in Mexico}

The first achievements in relation to electoral political equality for women emerged from 1916, when in Chiapas, Tabasco and Yucatan legal equality was recognized so that women could vote and be elected to positions of popular representation [8].

The right to vote for women in Mexico began on February 12, 1947, with the publication in the Official Gazette of the Federation of the Decree adding to article 115 to allow them participation as voters and as candidates, establishing that: "In Municipal elections will be attended by women, on an equal footing with men, with the right to vote and be voted".

However, it was on July 3, 1955, when women in Mexico first voted in a federal election. The foregoing, derived from the campaign promise made by the then presidential candidate Adolfo Ruiz Cortines two years earlier.

It was on October 17, 1953, once the legislative process was completed, that President Ruiz Cortines promulgated the constitutional reforms to articles 34 and 115, section I, in which the full rights of citizens are granted to mexican women.

In the 1955 federal elections, women went to the polls for the first time to cast their vote. On that occasion, federal deputies were elected to the XLIII Legislature. Despite the importance of this historical event, for being the first exercise of freedom of decision for women, the true democratization of citizenship took many more years to germinate, since tradition was still rooted in our country.

That is why 24 years had to pass before the suffrage of women was recognized, so that in 1979 Mexico had the first state governor (of Colima), Griselda Alvarez [9].

\section{Women who are part of political history in Mexico \\ Despite the fact that, regarding the number of} men who participate in politics, women are a very small group, we will list some of those who have already earned a place in the history of our country: 


\section{Women candidates for the Presidency of the Republic}

Until the first quarter of 2020, only five women have participated as candidates for the Presidency of the Republic: María del Rosario Ibarra de la Garza in 1982 and 1988, Cecilia Soto González and Marcela Lombardo Otero in 1994, Dora Patricia Mercado Castro in 2006, Josefina Vázquez Mota in 2012 and Margarita Ester Zavala Gómez del Campo in 2018.

It should be noted that, in Mexico, by 2020, no woman has held the position of President of the Republic.

\section{Women Governors in Mexico}

In the history of the country, only nine women have held the position of Governors, it should be noted that, of those nine leaders, two were interim and the rest did campaign and managed to beat their competitors at the polls.

They are Griselda Álvarez Ponce de León, in Colima from 1979 to 1985 , Beatriz Paredes Rangel, in Tlaxcala, from 1987 to 1992; Dulce María Sauri Riancho, from 1991 to 1993, and Ivonne Aracelly Ortega Pacheco, from 2007 to 2010, in Yucatán; Rosario Robles Berlanga, from 1999 to 2000, and Claudia Sheinbaum Pardo, from 2018 in office, in Mexico City; Amalia García Medina, in Zacatecas, from 2004 to 2010; Claudia Pavlovich Arellano in Sonora, since 2015 in office; and Martha Erika Alonso Hidalgo in Puebla, who was in office for only ten days, from December 14 to 24, 2018, the date on which she died in a plane crash.

The PRI is the party that has had the most women leaders, secondly, the PRD and finally PAN and MORENA with one [10].

\section{Women Secretaries of State}

From 1976 to 2020, that is, in a 44-year period, only 31 women have held the position of Secretary of State, thereby reaffirming the fact that women's participation in presidential cabinets has been low.

The first cabinet that had a woman as Secretary of State was that of the 1976-1982 administration, with Rosa Luz Alegria Escamilla, who served as Secretary of Tourism. In the period 19821988 there was no female Secretary of State.

In the 1988-1994 administration, there were two women occupying the position of Secretary of State: María de los Ángeles Moreno, in the Ministry of Fisheries; and María Elena Vázquez Nava, in the Secretariat of the General Comptroller of the Federation.
In the 1994-2000 presidential term, there were four women: Rosario Green Macías, in the Ministry of Foreign Relations; Julia Carabias Lillo, in the Ministry of the Environment, Natural Resources and Fisheries; Norma Samaniego de Villarreal, in the Office of the Comptroller and Administrative Development; and Silvia Hernández Enríquez, at the Ministry of Tourism. In the 2000-2006 cabinet, four women serves as Secretaries or State: Josefina Eugenia Vazquez Mota and Ana Teresa Aranda, in the Ministry of Social Development, María Teresa Herrera Tello, Secretary of Agrarian Reform; and Leticia Navarro Ochoa, Secretary of Tourism.

In the 2000-2006 cabinet, four women served as Secretaries of State: Josefina Eugenia Vázquez Mota and Ana Teresa Aranda, in the Ministry of Social Development, María Teresa Herrera Tello, Secretary of Agrarian Reform; and Leticia Navarro Ochoa, Secretary of Tourism.

In the 2006-2012 sexennium, seven women were Secretaries of State: Georgina Yamilet Kessel Martínez, Secretary of Energy from 2006 to 2009; Josefina Eugenia Vázquez Mota, Secretary of Public Education from 2006 to 2009; Patricia Espinosa Cantellano, Secretary of Foreign Relations since 2006; Gloria Guevara Manzo, Secretary of Tourism in 2010; María Beatriz Zavala Peniche, Secretary for Social Development; Marisela Morales Ibáñez, Attorney General of the Republic appointed in 2011 and Rosalinda Vélez Juárez, Secretary of Labor and Social Security, from 2011 to 2012.

In the 2012-2018 administration, there were five women working in eight Secretaries of State: Claudia Ruiz Massieu Salinas, in the Ministry of Foreign Relations and in the Ministry of Tourism; Rosario Robles Berlanga, in the Secretary of Social Development and in the Secretary of Agrarian, Territorial and Urban Development; Arely Gómez González, in the Secretariat of the Public Function and in the Federal Attorney General's Office; Mercedes Juan López, in the Ministry of Health; and María Cristina García Cepeda, at the Ministry of Culture.

In the current cabinet of the 2018-2024 administration, there are eight women serving as Secretaries of State, they are: Olga Sánchez Cordero, in the Ministry of the Interior; Alejandra Frausto Guerrero, in the Ministry of Culture; María Luisa Albores, in the Ministry of Social Development; Josefa González Blanco Ortiz Mena, in the Ministry of the Environment and Natural Resources; Norma Rocío Nahle García, in the Ministry of Energy; Graciela Márquez Colín, in the Ministry of Economy; Luisa María Alcalde, at the Ministry of Labor and Social Security, and Irma Eréndira Sandoval Ballesteros, at the Ministry of Public Function [11]. 


\section{Women Legislators in the Chamber of Deputies and in the Senate of the Republic}

In the Chamber of Deputies, during the legislatures, LXI, LXII and LXIII, the growth of women's participation in the political life of the country can be seen and this pattern is similar in local legislatures, significantly since 2014 . You can see that during the LXI Legislature, which ran from 2009 to 20012, there was a percentage of participation of Federal Legislators of $28.4 \%$, during the LXII Legislature, whose period was from 2012 to 2015, there was a representation of women of $37.0 \%$, and in the LXIII Legislature, which comprises from 2015 to 2018, there was a female participation of $42.6 \%$. The current legislature, the LXIV, whose inauguration was the 1 st. September 2018, is made up of $48.2 \%$ of the female gender, which represents 241 women, and $51.8 \%$ of the male gender, which is equivalent to 251 men [12].

In the Senate of the Republic, in the LVIII and LIX, LX and LXI, and LXII and LXIII legislatures, the participation of women was as follows: in the LVIII and LIX Legislatures, which ranged from 2000 to 2006, it was 15.6\%; In the LX and LXI Legislatures, whose period spanned from 2006 to 2012, there was a percentage of $17.2 \%$, and in the LXII and LXIII Legislatures, there was a representation of women of $32.8 \%$. The current legislature, LXIV, is made up of 63 women, who represent $49.21 \%$ as a percentage, and 65 men, who represent $50.78 \%$ of the total [13].

\section{"Las Juanitas de San Lázaro": an attempt to circumvent gender equality}

After the elections and protesting in the Chamber of Deputies in September 2009, 10 people, 2 men and 8 women applied for a license. Women would be replaced by alternates men and men by women. They were called the "Juanitas" of San Lázaro ", four women and two men belonged to the PVEM, two women to the PRI, one to the PRD and another to the PT. One of them leaves the seat to her husband, another to her brother, and the others to people with certain family, work or friendship relationships with leaders of their respective parties. There was already talk of modifying the law in the sense that substitutes are of the same sex. This being the case, this is a proof of the cupola arrangements of political parties to the detriment of the female presence in political positions, but as stated, several voices of women politicians and representatives of institutions such as Inmujeres and the IFE have already stated that the law must be reformulated or clarified so that this does not happen again [14].

This strategy was an attempt to violate the spirit of equity in the distribution of deputies that arose from the Federal Code of Institutions and Electoral Procedures (COFIPE). The aforementioned deputies requested an indefinite license to hand over the position to their substitutes, the majority of whom are male and linked to the "television section", as those of the PVEM were already identified for their proximity to Televisa and TV Azteca [15].

In detail, this was the situation in each case: For the PRI, Yulma Rocha Aguilar would give way to Guillermo Ruiz de Teresa, representative of the tricolor before the IFE; Ana María Rojas Ruiz would give way to Julián Nazar Morales, coffee leader in Chiapas. From the PRD, Olga Luz Espinosa Morales would leave for Carlos Esquinca Cancino to arrive. For the PVEM, Mariana Ivette Ezeta Salcedo would leave the seat to her brother Carlos Alberto Ezeta Salcedo; Carolina García Cañó asked for a license for the arrival of Alejandro del Mazo Maza, son of Alfredo del Mazo; Kattia Garza Romo would leave the seat to her husband Guillermo Cueva Sada, and Laura Elena Ledezma Romo would do the same with Maximino Fernández Ávila, Rafael Pacchiano Alamán would leave his place to Alejandra Lagunes, and Raymundo Vargas Sáenz to Karitina Sáenz Vargas and the PT, Anel Patricia Nava Pérez would leave the position in the hands of Primitivo Ríos Vázquez [15].

After the first legislative skirmish, at night the fraction of the PRI accused the President of the Board of Directors, Francisco Ramírez Acuña, of an inconvenient handling, because the session became a disorderly debate without the presidency specifying what the point was in essence to be discussed.

The Cofipe, in its article 219, stated that all the registration applications, both for the candidacies for deputies and for senators that the parties or the coalitions present before the IFE, should be integrated with at least 40 percent of candidates who own a same gender, trying to reach parity. Excepted from this are the relative majority candidacies decided by vote of each party.

The attempt to impose - via license application - those substitutes who attend the interests of the group or television companies, to the detriment of the proprietary legislators, was brought to the full chamber with the argument of defending the freedom that any person enjoys for deciding what that best suits your interests [15].

And precisely that criterion would prevail within a month, when once again the board of directors submitted to the plenary for consideration the same license applications that were questioned by a large section of deputies from the PAN, PRI and PRD. In that period, the tricolor party could make it clear to National Action that their collaboration would be necessary to accept the licenses, because it was expected that over three years some PAN members would be required by the Felipe Calderón government and they would have to request to separate from its legislative function. 
The PAN member Silvia Isabel Monge said: Today, in this Sixty-First Legislature, we realize what is the way in which some parties operate, how they come to occupy a seat. In National Action we know how to respect the citizen's will; the PRI tried to amend Monge's criticism, and in the voice of Hilaria Domínguez rejected that there were traces of illegality in the license applications, and expressed: I totally respect our colleagues who, in their full freedom, in their individuality, have taken that decision to separate from office; they will have their personal reasons, she justified.

Leticia Quezada, of the PRD, said that she did not share either the position of the PAN or that of the PRI: "We regret that less than 72 hours after this legislature was established, ten applications for licenses are being issued. In addition, that they are mostly women and that those who assume are men. Because once again women are used so that men can come to office...". Jaime Cárdenas, from the PT, considered that what is most striking is that none of those licenses requested by the fellow deputies express the reasons, the reasons, why they request them. I am concerned that this is a way to violate the gender quotas established by the electoral laws, both of the Cofipe and the electoral laws of the states [15].

Margarita Uranga, of the PAN, warned that "it is a shame, because it is indeed a fraud, a hoax to the voters, (they are) alternate deputies who do not have enough ... who do not dare to enter through the front door to this sovereignty, and that they have to use fellows vilely". The also PAN member Kenia López replied: This is not a matter of gender, comrades, it is a matter of respect for the dignity of people.

As a corollary, PRI legislator Omar Fayad replied that the gender quota is the most undemocratic.

\section{IFE and INMUJERES position}

In response to the request for a license from eight deputies and two deputies to hand over their alternates - mostly men - electoral counselor Macarita Elizondo said that this is frustrating, especially for those who say that we are already seeking a balance in terms of guarantee a gender quota for party-nominated candidates (60 and 40 percent). He stressed that there are initiatives in Congress that seek to modify the law to ensure affirmative action in favor of women. He added that, although the requests have not been due to subterfuge, it is a practice that has occurred in previous legislatures and that, on the initiative of senators, it is intended to ensure that gender quotas are guaranteed. Shortly before the culmination of the campaigns, the president of the National Institute for Women (Inmujeres), Rocío García Gaytán, urged the then candidates not to give in to the pressure to apply for a license to the position of federal deputies, in case of reaching the Legislative Palace of San Lázaro [15].
In accordance with their PRI, PRD and PVEM benches, the incumbents chose not to attend the ordinary sessions to accumulate absences and allow the President of the Board of Directors, the PAN member Francisco Ramírez Acuña, to call the substitutes automatically and without discuss the topic in plenary. According to the attendance lists of the 10 ordinary sessions, since September 3 when they submitted their license application, they did not attend sessions on different dates [15].

In accordance with the Constitution and the regulations for the internal government of the Congress of the Union, when a deputy accumulates 10 absences, the president of the Chamber may call the substitute, only informing the assembly, based on the powers conferred by the subsection $\mathrm{n}$ of article 23 of the Organic Law of the Congress of the Union, which states: Require the deputies who do not attend, to attend the sessions of the Chamber and communicate to the plenary, where appropriate, the measures or sanctions that correspond to foundation in, constitutional articles 63 and 64.

The second paragraph of article 63 indicates that "the deputies or senators who miss ten consecutive days, without just cause or without the prior license of the president of their respective Chamber ... resign to attend until the immediate period, calling of course the substitutes." While article 64 orders that deputies or senators who do not attend ordinary sessions will not receive their respective diet payment [16].

The term "Juanitas" comes from the nickname of Rafael Acosta Ángeles, alias "Juanito", who publicly promised at a rally before Andrés Manuel López Obrador, to resign in favor of Clara Brugada in case of being elected as Iztapalapa Delegation Chief, commissioned to which gave protest in 1st. October 2009, and from which he applied for a license that same day, under pressure, arguing health reasons.

\section{The "Manuelitas" of Chiapas}

In September 2018, the "Juanitas" phenomenon of 2009 was repeated, but now in the State of Chiapas, where it was reported that at least 43 local deputies and councilors in various municipalities of Chiapas and some multi-member legislators were pressured to give up and leave his place to a man; These women, on this occasion, have been called "Manuelitas", alluding to the governor, senator with a state license, Manuel Velasco Coello.

On this occasion, the electoral authority approved a point of agreement for the political spaces for women to be redistributed and reallocated; We must recognize the dedication of the federal electoral authority to attract the case and promote a solution with a gender perspective, pending to define what the investigation would be like to sanction those 
responsible for threats and coercion, since in violation of the law, they also politically violate women [17].

\section{Legislative Efforts in Mexico}

In Mexico letters have been taken in the matter on the issue of women's political participation, because there are in the Mexican Regulations, different laws that support this demand, such as: The Political Constitution of the States United Mexican States, 1st articles. and 41, the Federal Law to Prevent and Eliminate Discrimination, the General Law for Equality between Women and Men, the General Law on Women's Access to a Life Free of Violence, General Law on Electoral Institutions and Procedures (LEGIPE), General Law of Political Parties, Law of the National Commission of Human Rights, among others; As for Constitutional reforms, there are, in 2011: Human Rights Reform and in 2014: Electoral Reform in Gender Parity; and in terms of progress in public equality policy, there is the National Development Plan 2013-2018, the Program for Equal Opportunities and Non-Discrimination against Women 2013-2018, the Comprehensive Program to Prevent, Address, Punish and Eradicate Violence against Women 2014-2018.

\section{Good practices implemented by political parties for the training, promotion and development of women's political leadership in Mexico}

In compliance with the project "Follow-up of the budget for training, promotion and development of women's political leadership", and the activity identified as: "Disseminate good practices implemented by political parties for training, promotion and development of leadership policy of women ", contained in the Work Plan 2019-2020 of the Temporary Commission for the Strengthening of Gender Equality and Non-Discrimination in Political Participation (CTFIGYND), the following information is disseminated [18]:

The Protocol for the Implementation of Good Practices in the Exercise of Programmed Expenditure Resources: Training, Promotion and Development of Women's Political Leadership (CPDLPM), serves to establish orientation criteria and guidelines for action for national and local political parties. , in order to efficiently fulfill the purpose of exercising the resources for the CPDLPM, and it is an orientation tool for political parties at the national and local level to efficiently manage the resources of the CPDLPM heading, complying with the principles of: Certainty, Impartiality, Objectivity, Non-discrimination, Legality, Independence Universality, Previous planning established by the Electoral Court of the Federal Judicial Power (TEPJF), since for the INE, the exercise of $3 \%$ of the budget of political parties to promote the Training, Promotion and Development of Women's Political Leadership (CPDLPM) is a as a necessary condition to guarantee the constitutional principle of gender parity, according to Agreement INE / CG / 1306/2018, approved on September 22, 2019.

The Structure of the Protocol includes: 1. Regulatory framework, 2. Conceptual framework, 3. Planning of the Annual Work Program (PAT) for the CPDLPM, 4. Application of the resource in the CPDLPM subsections: a. Training and education for women's political leadership. b. Research, analysis, diagnosis and comparative studies c. Disclosure and dissemination, 5. Verification of the expenditure of the PAT of CPDLPM, 6. Problems and good practices for the exercise of the resources of the programmed expenditure and 7. Good practices carried out in other countries in the field of dissemination, training and research to strengthen leadership women's politician.

As for the Guiding Criteria Guiding Concepts Political Violence Against Women, the Protocol details the technical processes for planning, executing, and verifying the programmed expenditure resources that are granted to the CPDLPM. The Guiding Concepts of the Protocol: 1. They allow identifying the causes of gender inequality and proposing programs and activities that contribute to their reduction and elimination, putting the empowerment of women at the center of the action, 2. For an adequate planning and execution of the resources destined to the CPDLPM, it is essential to know the meaning of the following concepts that we have grouped into 4 categories: 1. Compensatory Measures, 2. Analytical Categories, 3. Political Participation and Political Leadership of Women and 4. Political Violence against Women.

The Protocol contemplates as Compensatory Measures: a) Affirmative Actions: Temporary measures whose purpose is to accelerate the participation in conditions of equality of women in any other field; b) Measures for equality: Deliberate actions, which public institutions determine to correct conditions of unequal treatment of persons and groups discriminated against in access and enjoyment of their human rights, freedoms, goods and public services; c) Political advancement of women: It is the reduction of inequality gaps between women and men in order to guarantee the full exercise of their political-electoral rights based on substantive equality to guarantee their political participation; and, d) Empowerment of women: It is a process by which women move from any situation of oppression, inequality, discrimination, exploitation or exclusion to a stage of consciousness, selfdetermination, autonomy and independence that manifests itself in the exercise of democratic power [18].

The aforementioned, among other aspects, are a sample of what the Protocol includes and that its application is of great value for the political participation of women in Mexico. 
As a proposal to measure substantive equality between women and men in Mexican parties", Flavia Freidenberg proposes an index to measure equality within party organizations and evaluates the participation of women in Mexican parties with the intention of dimensioning in to what extent do these parties promote equality between women and men as well as seek to identify the barriers women face within such organizations [7].

\section{CONCLUSION}

Women's political participation is the result of a series of movements organized by women themselves since the end of the 19th century and the beginning of the $20^{\text {th }}$; in fact, the 20th century was, for all intents and purposes, the century of women, it was where the most revolutionary changes took place. Simone de Beauvoir stated, for the first time, that the roles of men and women were born from a social construction, that is, something that society had created and imposed. The obstacles for women to access politics on equal terms, in terms of timing, conditions and percentage, have been tinged with violence. Thus, from the epic struggles of women to obtain the vote to the current concerted efforts in all countries of the world to establish quotas and reserves to increase the number of women elected as representatives, women have always had a strong interest in democracy. They have recognized that democratic participation is the fundamental means for women's interests to be represented and to receive a socially legitimate and sustainable regulatory response. If women need democracy, democracy also needs women [19].

Mexico is one of the few countries in the world that, to guarantee women's electoral and political rights, has adopted at the constitutional level the principle of parity for the integration of federal and local legislative candidacies. This regulation prevents political parties from using legal barriers to hinder the political participation of women as candidates [20].

And thanks to the changes in electoral legislation with the inclusion of a voluntary gender quota in 1993 until the implementation of gender parity in the legislative sphere in 2014 - all this together with the actions taken by electoral institutions, political representation of women has constantly and significantly improved, as indicated by the fact that, after the elections of July 1, 2018, Mexico is the fourth country with the highest proportion of women deputies in Congress (IPU, 2018). Although these advances have been observed at the legislative level, there are no similar results at the executive level. For example, the presidency has never been held by a woman; only nine women have been governors and, with data as of December 2017, only $14.2 \%$ of the municipal presidencies were occupied by women (Sistema de Indicadores de Género-Inmujeres, 2017) [21].
Currently, the Constitution mandates gender parity in legislative candidacies. Thanks to these changes, the presence of women has gone from 14 to $48 \%$ in Congress (IPU, 2018). However, outside the legislative sphere, progress has been notably slower. For example, between 1995 and 2000 only 3\% of the municipalities were headed by a woman (Inmujeres, 2009). From 2001, it began a gradual increase that reached 14\% in 2017 (Gender Indicator SystemInmujeres, 2017). At the municipal level, three types of obstacles to women's political participation have been identified: the challenges they face in being elected and reelected, those derived from the particular characteristics of elections in the municipal sphere and political violence [21]. Now, the women who head municipal presidencies went from $14 \%$ to $26 \%$. These results, in addition to confirming the usefulness of affirmative actions and parity as catalysts for women's political participation, present an opportunity to reflect on the circumstances and conditions under which women participate in politics.

Full citizenship is still a challenge for women, which, however, of the achievements achieved, is not consolidated with guarantees that support it and equal opportunities that place them as co-protagonists on the political stage, thus contributing to the strengthening of civil society. The barriers that hinder the empowerment of women and their participation in spaces of power are numerous, and too deep-rooted, since women tend to segregate in sectors traditionally considered to be feminine, which are usually low-paid. Thus, while almost $30 \%$ of women work in sectors related to care (education, health and domestic work), among men these sectors only occupy $6 \%$," according to an IDB study.

Among the objectives of making the political participation of women visible are achieving interest and analysis on the subject at a general level in society, as well as identifying aspects that allow building strategies focused on reducing gender gaps and on overcome the limitations that women still face in politics.

For democracy to exist, there must necessarily be respect, equal opportunities, competition, tolerance, recognition of diversity, conditions of equity, plurality, transparency and accountability, the competence of the actors in politics. Thus, political representatives are presented to citizens, with an image as a result of a process of political promotion, dissemination and communication, which should serve to promote women and men in representation and political leadership. in a certain time and society. Studies argue that, by increasing the political participation of women in a stage of democratization and transition to democracy, it is also necessary to consider the use of strategically adequate communication systems in terms of gender, which contribute to the construction of an inclusive 
image in participatory democratic society, considering the important role they play in change processes.

Women slowly begin to join the public space, supported by the name of gender category in the social sciences, especially by the different gender studies that ask about the subordination of women.

Mexican women continue to face obstacles to be candidates, elected representatives and to exercise the positions for which they are elected or appointed, which affect both their political participation and equal representation in institutions. Among these obstacles are the cultural ones, due to the beliefs that women are less able to be candidates, to win an election and / or to govern; the partisans, due to the weight of practices that hinder the selection of candidates, segregate women to the party bases and refer them to non-competitive districts; the politico-institutional ones, due to the validity of electoral systems that generate fewer opportunities for the election of female candidates or due to the absence of mechanisms of affirmative action and / or application of parity, and the structural ones due to care burdens and traditional roles that they limit women's options for dedicating themselves fully to politics [7].

Electoral parity laws, also called gender quotas or equity quotas, are a type of positive discrimination that consists of establishing for a position, a minimum percentage of people from a group that has historically been discriminated against; This percentage is close to the representation of members of the discriminated group in society. It is a practice that has become common in the electoral system of several countries, and is taken as a conquest of progressive feminism. A democracy in which quotas are set according to gender is often called parity democracy.

Phenomena such as the "Juanitas" and the "Manuelitas" should be avoided and punished, including all those involved, which in no way contribute to the achievements of the law to support the political participation of women in Mexico, since the system electoral aims to be democratic through gender quotas, designed just for the equitable access of women and should not and cannot be circumvented [22]. Since, on the contrary, it is manifested that the political parties continue to do it more out of obligation and to comply with what the law says, than because they really want to give women the opportunity.

Changes in laws and established jurisprudence have improved - read leveled - the conditions in which women and men participate in the public life of the country. However, efforts will be insufficient until both sexes are guaranteed the opportunity to fully develop their professional life project without limitation due to the gender to which they belong. Initially, the regulation of quotas served to put into practice the recognition of the rights achieved in matters of gender. The vision of consolidation, understood as effective access to candidacies and to public positions of election, sought a healthy balance from the effective equality of different social groups in access to positions of decision or popular election [23].

It is clear then that the participation and access of women in all areas goes hand in hand with the desire to lay the groundwork in legal matters so that it can happen within a framework of equity and that, to continue opening the way for political participation of women it is necessary to assume and respect the law and the spaces that have been opened for our participation, in addition to privileging ideas and talent regardless of whether it comes from a certain gender, that is, a change of mentality must be presented in society in general, since until today, the world has made unprecedented progress, but no country has achieved gender equality.

\section{REFERENCES}

1. Encyclopedia.banrepcultural.org. (s / f). Cultural network of the banco de la republica in colombiah. Retrieved on 03 of 04 of 2020, from http://enccyclopedia.banrepcultural.org: http://enccyclopedia.banrepcultural.org/index.php? title=participaci\%c3\%b3n_pol\%c3\%adtica

2. Puleo, A. (2008). The challenge of gender equality. Madrid, spain: new library.

3. Becerra, L. (september 2007). Www.iknowpolitics.org/es. Retrieved on april 10, 2020 , from https://www.iknowpolitics.org/es/knowledgelibrary/case-study/participaci\%c3\%b3npol\%c3\%adtica-de-las-mujeres-en-centroam $\%$ c3\% a9rica-ym\% c3\% a9xico

4. Odimba On Etambalako Wetshokonda, J. C. (julydecember 2017). Indigenous women and their right to political participation in mexico. Prolegomena. Rights and values, xx (40), 145-158, xx (40), 147. Retrieved on 03 of 04 of 2020, from www.https: //www.redalyc.org/articulo.oa? Id = 87652654010 .

5. Ferrón, S. (february 2006). Women and political power inequality as a norm. (1. Gómez encinas, ed.) Bet. Journal of social sciences (25), 1-25.

6. Chamber of Deputies. (01 of 06 of 2020). Www.diputados.gob.mx, from http://www.diputados.gob.mx/leyesbiblio/pdf/lgim h_140618.pdf

7. Freidenberg, F. (2017). Www.ine.mx. (u. N. Mexico, editor) retrieved on 04/04/2020, from https://www.ine.mx/wpcontent/uploads/2019/04/la_representacion_politic a_de_las_mujeres_en_mex.pdf

8. Political Animal. (08 of 03 of 2013). Retrieved on 04/11/2020, from https://www.animalpolitico.com: https://www.animalpolitico.com/2013/03/lamujer-y-la-politica-en-mexico/ 
9. National institute for federalism and municipal development. (03 of 07 of 2019). Www.gob.mx. Retrieved on april 1, 2020, from https://www.gob.mx/inafed/articulos/64-

aniversario-del-voto-de-la-mujer-en-una-eleccionfederal-en-mexico.

10. López, E. (12 of 12 of 2018). Www.periodicocentral.mx. Retrieved on 04/10/2020, from https://www.periodicocentral.mx/2018/gobierno/it em/28129-cuantas-gobernadoras-ha-tenga-mexicomartha-erika-alonso-y-claudia-sheinbaum-se -addto-the-list

11. Government of The Republic. (s.f.). Www.gob.mx. Retrieved on 04/10/2020

12. Chamber Of Deputies. (s.f.). Www.diputados.gob.mx. Retrieved on 04/10/2020, from http://sitl.diputados.gob.mx/lxiv_leg/cuadro_gener o.php

13. Senate of The Republic. (s.f.). Www.senado.gob.mx. Retrieved on 04/10/2020, from

https://www.senado.gob.mx/64/senadores/integrac ion

14. Fernández, A. (05 of 2011). Www.redalyc.org. (u. A. Xochimilco, editor) retrieved on april 11, 2020, from

https://www.redalyc.org/pdf/595/59520783010.pdf

15. 15. Garduño, r., méndez, e., \& urrutia, a. (04 of 09 of 2009). Www.jornada.com.mx. Retrieved on 08 of 04 of 2020, from https://www.jornada.com.mx/2009/09/04/politica/ 003n1pol

16. Méndez, E., \& Garduño, R. (02 of 10 of 2009). Www.jornada.com.mx. Retrieved on 08 of 04 of 2020, from https://www.jornada.com.mx/2009/10/02/politica/ 008n3pol
17. Pimienta, X. (19 of 09 of 2018). Www.forbes.com.mx. Retrieved on 04/12/2020, from https://www.forbes.com.mx/juanitas-ymanuelitas-la-historia-de-repite/

18. National Electoral Institute. (s.f.). Www.igualdad.ine.mx. (ine, editor) recovered on 05 of 04 of 2020, from https://igualdad.ine.mx/wpcontent/uploads/2020/03/infografia_protocolo_bue nas_practicas_recursos_cpdlpm_correc14.pdf

19. United Nations. (2008). Www.un.org. Retrieved on 05/04/2020, from https://www.un.org/es/events/democracyday/2008/ pdf/democracyandwomen.pdf

20. Gender Equality Observatory. (05 22, 2019). Www.oig.cepal.org. Retrieved on 04/11/2020, from

https://oig.cepal.org/es/documentos/participacionpolitica-mujeres-nivel-municipal-procesoelectoral-2017-2018

21. Un Women. (12 of 2018). Www2.unwomen.org. Retrieved on april 11, 2020, from https://www2.unwomen.org/-

$/$ media/field $\% 20$ office $\% 20$ mexico/documentos/pu blicaciones/2019/participacin \%20poltica\%20de\%2 0las\%20mujeres\%20a\%20nivel\%20municipal_pro cess \% 20electoral\% 202017_2018.pdf? La = es \& vs $=3303$

22. Camil, J. (18 of 09 of 2009). Www.jornada.commx. Retrieved on 08 of 04 of 2020, from https://www.jornada.com.mx/2009/09/18/politica/ $021 \mathrm{a} 2 \mathrm{pol}$

23. Ugalde, L., \& Hernández, S. (2017). Strengths and weaknesses of the mexican electoral system. Federal and local perspective. Mexico: electoral tribunal. Obtained from https://www.te.gob.mx/publicaciones/sites/default/ files//archivos_libros/fortalezas $\% 20 \mathrm{y} \% 20$ debilida d\%20de1\%20sistema\%20electoral\%20mexicano.\% 20 perspectiva $\% 20$ federal $\% 20 y \% 20$ local.pdf. 